\title{
Analysing Factors Influencing Occupational Benzene Exposure Concentration in Loading Operations at Gasoline Storage and Distribution Facility in Developing Countries
}

\author{
Antoine Francis Obame Nguema ${ }^{1 *}$, Akihiro Tokai², Hoa Thi Nguyen ${ }^{3}$, Naoya Kojima ${ }^{4}$ \\ ${ }^{1}$ Osaka University, Department of Engineering, Graduate School of Engineering, Division of Sustainable Energy and \\ Environmental Engineering, Environmental Management Laboratory (Tokai Laboratory) \\ 2-1 Yamadaoka Suita City Suita,, Osaka Prefecture, Japan \\ ${ }^{2}$ Osaka University, Department of Engineering, Graduate School of Engineering, Division of Sustainable Energy and \\ Environmental Engineering, Area of Environmental Management \\ 2-1 Yamadaoka Suita City Suita,, Osaka Prefecture, Japan \\ ${ }^{3}$ Osaka University, Department of Engineering, Graduate School of Engineering, Division of Sustainable Energy and \\ Environmental Engineering, Assistant Professor of Environmental Management laboratory (Tokai Laboratory) \\ 22-1 Yamadaoka Suita City Suita,, Osaka Prefecture, Japan \\ ${ }^{4}$ Osaka University Graduate School of Engineering Department of Environment and Energy Engineering \\ Associate Professor of Environmental Management (Tokai Laboratory) \\ 2-1 Yamadaoka Suita City Suita,, Osaka Prefecture, Japan \\ *Corresponding author's email: obame [AT] em.see.eng.osaka-u.ac.jp
}

\begin{abstract}
Refined petroleum products are handled in gasoline storage and distribution facility to be conveyed to the end users. These are done through loading operations. During loading operations benzene vapor escape from various emissions sources and the level of benzene exposure concentration alter, based on several factors. However, the lack of monitoring data in some oil exporting developing countries, makes challenging the chemical exposure assessment in these facilities. Therefore, identifying, prioritizing and understanding the interactions of factors that influence benzene exposure concentration during loading operations at gasoline storage and distribution facility in developing country would help management to conduct a more comprehensive and accurate chemical risk assessment. The interpretive structural modeling methodology for identifying the direct and indirect relationships between the factors describe the situation far more accurately than an individual factor taken in isolation. Therefore, represents the suitable tool to conduct our research. The results of this study reveals that the identified factors such as: 'product', 'regulation', 'working practices'” and 'installation'” are the most influential for benzene exposure concentration level at gasoline storage and distribution facility in developing countries. Based on those results, management should tackle first these factors before others and emphasize on strategy to improve these factors with the view of providing a safe working place through a benzene exposure concentration level lower than the occupational exposure limit.
\end{abstract}

Keywords--- benzene concentration; developing country; gasoline storage and distribution facility; interpretive structural model; identified factors

\section{INTRODUCTION}

In order to convey refined petroleum products from the refinery to the end users, gasoline storage and distribution facility (GSDF) is considered as a critical step to successfully achieve this operation. GSDF is concerned with the handling for storage and transfer of refined petroleum products in loading locations via pipelines to different petroleum storage transport mode (barge tanks, rail tank, truck tank) [1]. GSDF is as the same time an useful tool for a nation's economic growth and health issue to its working population; through economic gain from loading operations activities and health 
damage such as cancer risk from workers' exposure to petroleum products respectively. Loading operation is the process of transferring petroleum refined products from bulk storage tank to operating tank [2]. It is also the transfer of petroleum refined products from storage tank to various petroleum storage transport mode such as; barge tank; rail tank; truck tank, through pipelines, hoses, flexible joint arms [1]. Loading operation is the main activity in GSDF and required well trained working force and functional equipment to be run properly [2]. These requirements act as a guaranty for a safe working environment freed from any economic loss and occupational injure. However, during loading operations and storage of petroleum refined products, such as gasoline, benzene vapors escape into the atmosphere [3]. Air toxics are released from the GSDF during gasoline loading truck tank; rail tank; storage tank; barge tank and from other sources like the vapor leaks at loading pumps, valves and other equipment in the facility [4]. In several articles, occupational benzene exposure concentration during loading operations are discussed and the benzene concentration in these various studies exceeded the different occupational exposure limit set throughout each period [1, 3, 5, 6, 1 7]. Thus, GSDF's workers are exposed to high level of benzene concentration during loading operations [13]. Benzene is one of the volatile components of petroleum products, like gasoline and is an established carcinogenic chemical for human health by the International Agency of Research on Cancer [14]. Short term human exposures to benzene can give rise to various adverse effects such as headaches, dizziness, inability to concentrate, impaired short term memory and tremors [15] and is considered as acute exposure effects. While long term human exposure can give rise to more complex health effects including haematotoxicity, genetoxicity, immunological and reproductive effects as well as various cancers [16] and is considered as chronic exposure effects. In general, acute exposure effects are considered to be reversible, while chronic exposure effects are probably irreversible [17]. Although, contamination with benzene is mostly due to uncontrolled industrial activity and lack of the awareness of workers [18], the magnitude of the problem is said to be grave for developing countries [19]. In most oil exporting developing countries, a comprehensive and harmonious data collecting systems is unavailable. A standard checklist, a material safety data sheet and structured interviews of staff concerning health hazard in petroleum loading operations are used as chemical assessment method $[19,20]$. This approach remains unsatisfactory to perform a more accurate chemical risk assessment at GSDF in developing country. The literature review suggests that no study has been taken that investigate explicitly the interactions among the factors that impact benzene exposure concentration during loading operations and proposes an interpretive structural modeling (ISM) based model for these factors. This study attempts to identify the factors that influence benzene exposure concentration through literature review and; experts' opinions and further develops a contextual relationship among these identified factors using ISM method. Furthermore, it also proposes a hierarchy of benzene exposure concentration factors that would help the management to understand and to be aware of the identified factors for a more accuracy in performing a chemical assessment at gasoline storage and distribution facility in developing countries. The main objectives of this study are as below mentioned:

$>$ To identify and rank the factors influencing benzene exposure concentration at GSDF in developing countries during loading operations.

$>$ To find out the interaction among identified factors using ISM

$>$ To discuss managerial implication of this study and suggest directions for future studies.

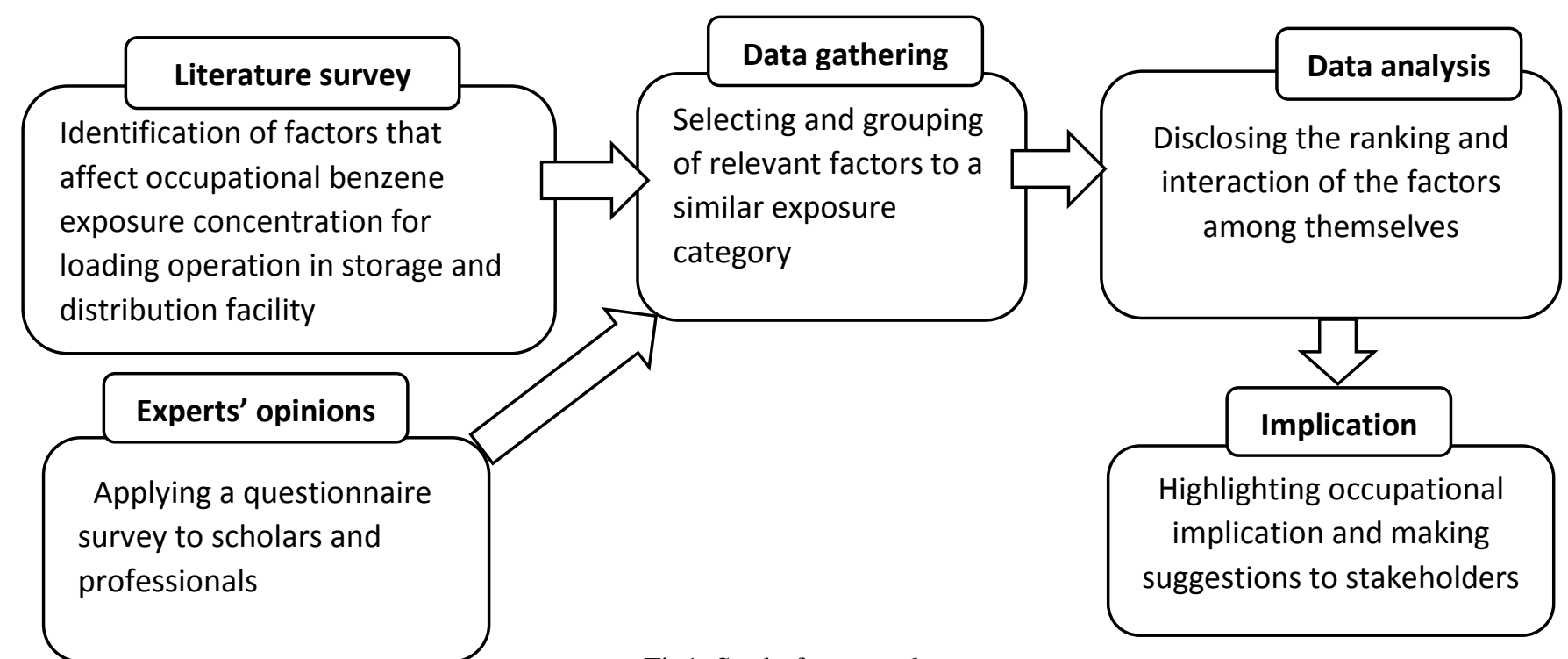

Fig1. Study framework 


\section{MATERIAL AND METHODS}

In the section 2.1., the literature survey on the factors influencing benzene exposure concentration during loading operation in GSDF are identified. Section 2.2., presents the results from the questionnaire-survey of the experts. Section 2.3., explains the challenges of making a chemical assessment in developing countries. Section 3., shows the results and the discussion; and finally the section 4 . presents the conclusion.

\subsection{Identification of factors influencing benzene exposure}

In our study, the loading operations from GSDF are focused on loading truck tank operation, loading storage tank operation and loading barge tank operation. In these three working locations, factors that influence benzene exposure concentration were identified during loading operations from the literature review. Then, the factors were grouped into a larger representation of factors influencing benzene exposure concentration. A questionnaire survey was addressed to professionals; scholars and the results were aggregated to the large group of identified factors. We applied the interpretive structural modeling (ISM) to factors of the large group. The results were meant to be used to support management in decision making and stakeholders. From the literature review, benzene exposure concentration during loading operation in GSDF has always been high in the past $[8,13,21]$. Exposures to benzene during loading truck tank operation occur as a result of several actions. The major sources of exposures are as results of gasoline flow into the empty tank; displacing hydrocarbon vapors; leaking fill lines and draining of tanks also result in exposures from evaporation of the gasoline [22]. The top loading and bottom loading tend to give high benzene exposure concentration during truck tank loading operation [21]. At the barge loading operation, the major sources of high benzene exposure concentration occur from the manual sounding of the tanks; the phase of loading when the tanks were topped up [23]. At the loading storage operation, defective valves; gauging; lack of external floating roof tank; lack of internal roof; lack of vertical roof tank; gauging at the roof top $(24,26]$. Then, after identified the sub-factors influencing benzene exposure concentration during loading operation, from the literature review, each sub-factors were grouped into a larger group of factors. The larger group of factors was set, through a generic questionnaire from occupational exposure assessment such as: what product workers handle? Under which meteorology conditions workers perform the task? What task workers perform? How do workers perform the task? Where do workers perform the task? Which regulations cover the task performs by workers? The table 1 . below summarize the identified factors and sub-factors influencing benzene exposure concentration during loading operation.

\subsection{Questionnaire-based survey}

The aim of this questionnaire-based survey was to help developing the first step towards building an ISM-based model by experts, which is the relationship matrix. The respondents were required to point out the importance of 6 listed factors on the five-point Likert scale and results were weighted based on respondent category. The questionnaire was intended on the five-point Likert scale, with the scale, '1', '2', '3', '4', '5' corresponding to 'Very low', 'Low', 'Moderate', High, 'Very high', respectively. The questionnaire was applied to Engineers in 'Health Safety Environment', 'Operators in charge of loading operations', 'student in the field of Health Safety Environment' and 'Any person willing to participate'. In total, 25 questionnaires were submitted to the 4 categories mentioned above. Only 11 questionnaires were received out of the 25 questionnaires. Thus, making a response rate of $44 \%$, which is above the $20 \%$ rates, considered as particularly undesirable for survey findings [25]. The description of the questionnaire-based survey and the factors ranking are presented in Table 2 and Table 3 respectively.

\subsection{ISM method}

Interpretive Structural Modeling (ISM) was first proposed by J. Warfield in 1973 to analyze the complex socioeconomic systems [36]. Moreover, ISM is a computer-assisted learning process that enables individuals or groups to develop a map of the complex relationships between the many elements involved in a complex situation. Further, ISM is a qualitative tool with the objective of understanding the complex relationship among elements to a particular subject [36]. ISM is a well-established methodology for identifying relationships among specific items, which define a problem or an issue. This approach has been increasingly used by various researchers to represent the interrelationships among various elements related to the issue. ISM approach starts with an identification of variables, which are relevant to the problem or issue. Then, a contextually relevant subordinate relation is chosen. Having decided the contextual relation, a structural selfinteraction matrix (SSIM) is developed based on pairwise comparison of variables. After that, SSIM is converted into a reachability matrix $(\mathrm{RM})$ and its transitivity is checked. Once transitivity embedding is complete, a matrix model is obtained. Further, the partitioning of the elements and an extraction of the structural model called ISM is derived [33]. In our study, we attempt to understand the relationship and the importance between the factors influencing benzene exposure concentration at GSDF during loading operation in developing countries by using ISM approach. 
Table 1. Barriers related factors and sub-factors in benzene exposure

\begin{tabular}{|c|c|c|c|c|}
\hline Factors & $\begin{array}{l}\text { Barrier } \\
\text { related }\end{array}$ & Sub-factors & References & Explanation \\
\hline \multirow[t]{3}{*}{ P-Product } & P1 & $\begin{array}{l}\text { high level of benzene } \\
\text { contain }\end{array}$ & $\begin{array}{l}\text { (RAGHAVAN et } \\
\text { al., 2005) }\end{array}$ & \multirow{3}{*}{$\begin{array}{l}\text { The product } \\
\text { characteristics } \\
\text { (benzene level } \\
\text { contain, evaporation } \\
\text { process etc.) that } \\
\text { impact benzene } \\
\text { exposure } \\
\text { concentration. }\end{array}$} \\
\hline & $\mathrm{P} 2$ & Evaporation process & $\begin{array}{l}\text { Xochitl Cruz-Núñez } \\
\text { et al., 2003) }\end{array}$ & \\
\hline & P3 & Quantity of gasoline sold & $\begin{array}{l}\text { (Xochitl Cruz- } \\
\text { Núñez et al., 2003) }\end{array}$ & \\
\hline \multirow[t]{3}{*}{$\begin{array}{l}\text { M- } \\
\text { Meteorology } \\
\text { conditions }\end{array}$} & M1 & Wind speed & $\begin{array}{l}\text { (Spyros } \\
\text { Karakitsios et al., } \\
2007)\end{array}$ & \multirow{3}{*}{$\begin{array}{l}\text { The different } \\
\text { environmental } \\
\text { characteristics (wind } \\
\text { speed, temperature } \\
\text { etc.) affecting } \\
\text { benzene exposure } \\
\text { concentration. }\end{array}$} \\
\hline & M2 & Temperature level & $\begin{array}{l}\text { (Spyros } \\
\text { Karakitsios et al., } \\
2007)\end{array}$ & \\
\hline & M3 & wind direction & $\begin{array}{l}\text { (Tsai-Yin Lin et al., } \\
\text { 2004) }\end{array}$ & \\
\hline \multirow[t]{3}{*}{$\begin{array}{l}\text { N-Nature of } \\
\text { the task }\end{array}$} & $\mathrm{N}-1$ & regular task & $\begin{array}{l}\text { (Eun Kyo Chung et } \\
\text { al., 2016) }\end{array}$ & \multirow{3}{*}{$\begin{array}{l}\text { The type of tasks } \\
\text { (loading operations, } \\
\text { maintenance } \\
\text { operation etc.) that } \\
\text { affect benzene } \\
\text { exposure } \\
\text { concentration. }\end{array}$} \\
\hline & $\mathrm{N}-2$ & Loading tasks & (Pandya et al., 2005) & \\
\hline & $\mathrm{N}-3$ & Maintenance tasks & $\begin{array}{l}\text { (Eun Kyo Chung et } \\
\text { al., 2016) }\end{array}$ & \\
\hline \multirow[t]{3}{*}{$\begin{array}{l}\text { W-Working } \\
\text { practices }\end{array}$} & $\mathrm{W}-1$ & $\begin{array}{l}\text { Lack of appropriate } \\
\text { personal protective } \\
\text { equipment used }\end{array}$ & $\begin{array}{l}\text { From author's } \\
\text { experience base. }\end{array}$ & \multirow{3}{*}{$\begin{array}{l}\text { The workers skills } \\
\text { level and behavior } \\
\text { that affect benzene } \\
\text { exposure } \\
\text { concentration. }\end{array}$} \\
\hline & $\mathrm{W}-2$ & $\begin{array}{l}\text { Irregular procedure } \\
\text { application }\end{array}$ & $\begin{array}{l}\text { From author's } \\
\text { experience base. }\end{array}$ & \\
\hline & $\mathrm{W}-3$ & Lack of regular training & $\begin{array}{l}\text { From. author's } \\
\text { experience base. }\end{array}$ & \\
\hline \multirow[t]{4}{*}{$\begin{array}{l}\text { R- } \\
\text { Regulations }\end{array}$} & R-1 & $\begin{array}{l}\text { Lack of regular chemical } \\
\text { assessment reports }\end{array}$ & $\begin{array}{l}\text { From author's } \\
\text { experience base. }\end{array}$ & \multirow{4}{*}{$\begin{array}{l}\text { The lack of different } \\
\text { laws, regulations and } \\
\text { procedures that } \\
\text { provide a safe } \\
\text { working } \\
\text { environment from } \\
\text { benzene exposure } \\
\text { concentration. }\end{array}$} \\
\hline & $\mathrm{R}-2$ & $\begin{array}{l}\text { Lack of workers shift } \\
\text { interchange legislation }\end{array}$ & $\begin{array}{l}\text { (Papalouska et al., } \\
\text { 2007) }\end{array}$ & \\
\hline & $\mathrm{R}-3$ & $\begin{array}{llr}\text { Lack of policy } & \text { in } \\
\text { occupational } & \text { safety } & \text { and } \\
\text { health } & & \\
\end{array}$ & $\begin{array}{l}\text { (Tulashie et al., } \\
\text { 2007) }\end{array}$ & \\
\hline & $\mathrm{R}-4$ & $\begin{array}{l}\text { Lack of an update of } \\
\text { industrial health policy }\end{array}$ & $\begin{array}{l}\text { (Ezejiofor TIN, et } \\
\text { al., 2014) }\end{array}$ & \\
\hline \multirow[t]{5}{*}{ I-Installation } & $\mathrm{I}-1$ & $\begin{array}{l}\text { Lack of vapor Recovery } \\
\text { system }\end{array}$ & $\begin{array}{l}\text { (Verma et al., 1992; } \\
\text { Xochitl Cruz-Nuñez } \\
\text { et al., 2003) }\end{array}$ & \multirow{5}{*}{$\begin{array}{l}\text { The lack of different } \\
\text { equipment, } \\
\text { mechanicals tools, } \\
\text { technology that } \\
\text { provide safer work } \\
\text { from benzene } \\
\text { exposure } \\
\text { concentration. }\end{array}$} \\
\hline & $\mathrm{I}-2$ & $\begin{array}{l}\text { Defective } \\
\text { (equipment) }\end{array}$ & (Jackson, 2005) & \\
\hline & $\mathrm{I}-3$ & External floating roof tank & (Jackson, 2005) & \\
\hline & $\mathrm{I}-4$ & Vertical fixed roof tank & (Jackson, 2005) & \\
\hline & $\mathrm{I}-5$ & $\begin{array}{l}\text { Lack of automated } \\
\text { operation }\end{array}$ & (Nordlinder, 1989) & \\
\hline
\end{tabular}




\section{RESULTS AND DISCUSSION}

\subsection{Practical application of ISM:}

After selecting the identified factors from the literature review and with the author's opinion, we considered them as elements which are related to define the problem. Then, a contextual relationship is established among elements through pairwise technique. Step1: making a Structural Self-Interaction Matrix (SSIM) In other to analyze the identified factors, a contextual relationship of "leads" or "influences" type is chosen. This means that one identified factor influences another identified factor. There are four symbols V; A; X; O; used in ISM to express the interrelationship between two elements $(i$ and $j$ ) [34]. The symbol $\mathrm{V}$ represents the relationship whereby the identified factor $i$ influences the identified factor $j$. For example, the identified factor 'meteorology condition'" influences the identified factor "'product'. During a gasoline loading operation "meteorology condition" through a "wind speed and direction" influences "product"' by the "'evaporation process", which changes the benzene exposure concentration level at the working location. Though, the identified factor "'product" through the "high level benzene content'" cannot influences "'meteorology condition"' by the "'temperature level', to enable a change in benzene exposure concentration level, as example for the symbol V. The symbol A represents the relationship between the identified factors $j$ and $i$. For instance, the identified factor "product" does not influence the identified factor "nature of the task", because if there is no operation taking place the "product" will maintain its benzene exposure concentration level. In the other hand, during loading operation and in particular for a specific task performed, the benzene exposure concentration level changed. The symbol $\mathrm{X}$ is used to express that both identified factors influence each other and direction relations goes for both. The identified factors "nature of the task" and "working practices" influence each other. The "nature of the task" influences "'working practice", because the task to be performed determine a specific working practice to maintain a safe level of benzene exposure concentration. The working practice used is adapted to the task performed.

Table 2. Structural self-interactive matrix (SSIM)

\begin{tabular}{|c|c|c|c|c|c|c|}
\hline \multicolumn{2}{|l|}{ Factors $(\mathbf{S i})$} & S6 & S5 & S4 & S3 & S2 \\
\hline $\begin{array}{l}\text { meteorology } \\
\text { conditions }\end{array}$ & $\mathrm{S} 1$ & $\mathrm{O}$ & $\mathrm{O}$ & $\mathrm{V}$ & A & $\mathrm{V}$ \\
\hline Product & S2 & A & $\mathrm{V}$ & $\mathrm{V}$ & A & \\
\hline Nature of the task & S3 & $\mathrm{V}$ & $\mathrm{V}$ & $\mathrm{X}$ & & \\
\hline Working practices & S4 & A & $\mathrm{V}$ & & & \\
\hline Regulations & S5 & $\mathrm{V}$ & & & & \\
\hline Installation & S6 & & & & & \\
\hline
\end{tabular}

Finally, the symbol $\mathrm{O}$ expresses the absence of relationship between the identified factor $i$ and $j$, such as the identified factors "'meteorology condition"' and the "'installation". The "wind speed" or the "temperature level" cannot influence the "lack of vapor recovery system", and vice-versa. During loading operation, the "'lack of vapor recovery", system cannot influence "wind speed" or "temperature level", to alter the benzene exposure concentration level. Based on the above rules on contextual relationships, the SSIM was built as shown in the table 2. Step2: converting SSIM into an initial Reachability Matrix (RM) In other to convert the SSIM to initial reachability matrix, the four symbols (V, A, X, O) were substituted by 1 or $0 \mathrm{~s}$ in the initial reachability. The rules to convert SSIM into initial reachability matrix are as follows: if the $(i, j)$ entry in the SSIM is $\mathrm{V}$, then the $(i, j)$ entry in the RM becomes 1 and the $(j, i)$ entry becomes 0 . If the $(i, j)$ entry in the SSIM is A, then the $(i, j)$ entry in the RM becomes 0 and the $(j, i)$ entry becomes 1. If the $(i, j)$ entry in the SSIM is X, then the $(i, j)$ entry in the RM becomes 1 and the $(j, i)$ entry becomes 0 . If the $(i, j)$ entry in the SSIM is 0 , then the $(i, j)$ entry in the RM becomes 0 and the $(j, i)$ entry becomes 0 . Coming after this rule to obtain the initial RM presented in table 3, the transitivity relationship is checked (Attri et al., 2013). The value 1 is allocated to the element which gives the direction of the matrix and the value 0 to the element which undergoes it. Additionally, the value 1 is giving to the entry when the elements influences each other and the value 0 , when there is no relationship between the elements in the matrix. 
Table 3. Initial reachability matrix

\begin{tabular}{|l|l|l|l|l|l|l|l|}
\hline Factors (Si) & & S1 & S2 & S3 & S4 & S5 & S6 \\
\hline $\begin{array}{l}\text { meteorology } \\
\text { conditions }\end{array}$ & S1 & 1 & 1 & 0 & 1 & 1 & 0 \\
\hline $\begin{array}{l}\text { Product } \\
\text { S2 }\end{array}$ & 0 & 1 & 0 & 1 & 1 & 1 \\
\hline $\begin{array}{l}\text { Nature of the task } \\
\text { Working practices }\end{array}$ & S3 & 0 & 1 & 1 & 1 & 1 & 1 \\
\hline $\begin{array}{l}\text { Regulations } \\
\text { Installation }\end{array}$ & S5 & 0 & 1 & 0 & 1 & 1 & 1 \\
\hline
\end{tabular}

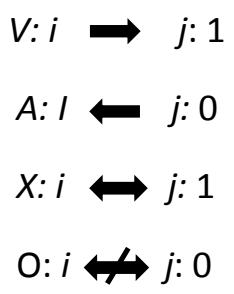

According to Sharma, the transitivity concept is defined as how the element $x$ relates to element $y(x \mathrm{R} y)$; and how the element $y$ relates to element $z(y \mathrm{R} z)$; thus, transitivity implies that element $x$ will also relate to element $z(x \mathrm{R} z)$. Having done the transitivity relationship, the initial RM can be converted to a final RM as shown in the table 4. [35].

Table 4. Final reachability matrix

\begin{tabular}{|c|c|c|c|c|c|c|c|}
\hline \multicolumn{2}{|l|}{ Factors (Si) } & \multirow{2}{*}{$\begin{array}{l}\text { S1 } \\
1\end{array}$} & \multirow{2}{*}{$\begin{array}{l}\text { S2 } \\
1\end{array}$} & \multirow{2}{*}{$\begin{array}{l}\mathbf{S 3} \\
1 *\end{array}$} & \multirow{2}{*}{$\begin{array}{l}\text { S4 } \\
1\end{array}$} & \multirow{2}{*}{$\begin{array}{l}\text { S5 } \\
1\end{array}$} & \multirow{2}{*}{$\begin{array}{l}\text { S6 } \\
1 *\end{array}$} \\
\hline $\begin{array}{l}\text { meteorology } \\
\text { conditions }\end{array}$ & $\mathrm{S} 1$ & & & & & & \\
\hline Product & $\mathrm{S} 2$ & 0 & 1 & 0 & 1 & 1 & 1 \\
\hline Nature of the task & $\mathrm{S} 3$ & 0 & 1 & 1 & 1 & 1 & 1 \\
\hline Working practices & $\mathrm{S} 4$ & 0 & $1 *$ & 0 & 1 & 1 & $1 *$ \\
\hline Regulations & S5 & 0 & 1 & 0 & 1 & 1 & 1 \\
\hline Installation & S6 & 0 & 1 & 1 & $1 *$ & 1 & 1 \\
\hline
\end{tabular}

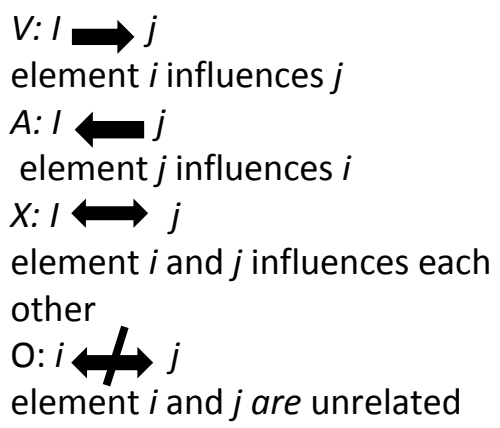

Step3: level of partitions on final RM From the final RM, the reachability set, the antecedent set and intersection set were derived. The reachability set consists of the barrier itself and the other barrier that it may influence; while the antecedent set consists of the barrier itself and the other barrier that may affect it. Then, the intersection of these sets is derived for all the barriers, and the levels of the different barriers are determined [34]. The barriers for which reachability sets and intersection sets are similar, occupy the top level of the ISM hierarchy. The top-level barriers are those barriers that will not influence the other barriers above their own level in the hierarchy. Once the top-level barriers are identified, it is removed from consideration. Then, the same process is repeated to find out the barriers in the next level. This process is continued until the level of each barrier is found; and these levels help in building the diagraph and ISM model [33, 34]. In our study, the 6 identified factors, as well as their reachability set, the antecedent set, intersection set and levels were disclosed as shown the table 7,8 and 9 . 
Table 5. Iteration I

\begin{tabular}{|l|l|l|l|l|}
\hline $\begin{array}{l}\text { Factors } \\
\text { (Si) }\end{array}$ & $\begin{array}{l}\text { Reachability set } \\
\text { R (Si) }\end{array}$ & $\begin{array}{l}\text { Antecedent set } \\
\text { A ( (Si) }\end{array}$ & $\begin{array}{l}\text { Intersection set } \\
\text { R (Si) } \cap \text { A ( }(\mathbf{S i})\end{array}$ & Level \\
\hline S1 & S1, S2, S3, S4, S5, S6 & S1 & S1 \\
\hline S2 & S2, S4, S5, S6 & S1, S2, S3, S4, S5, S6 & S2, S4, S5, S6 & \\
\hline S3 & S2, S3, S4, S5, S6 & S1, S3, S6 & S3, S6 & I \\
\hline S4 & S2, S4, S5, S6 & S1, S2, S3, S4, S5, S6 & S2, S4, S5, S6 & \\
\hline S5 & S2, S4, S5, S6 & S1, S2, S3, S4, S5, S6 & S2, S4, S5, S6 & \\
\hline S6 & S2, S3, S4, S5, S6 & S1, S2, S3, S4, S5, S6 & S2, S3, S4, S5, S6 & \\
\hline & & & &
\end{tabular}

Table 6. Iteration II

\begin{tabular}{|l|l|l|l|l|}
$\begin{array}{l}\text { Factors } \\
(\mathbf{S i})\end{array}$ & $\begin{array}{l}\text { Reachability set } \\
\mathbf{R}(\mathbf{S i})\end{array}$ & $\begin{array}{l}\text { Antecedent set } \\
\mathbf{A}(\mathbf{S i})\end{array}$ & $\begin{array}{l}\text { Intersection set } \\
\mathbf{R}(\mathbf{B i}) \cap \mathbf{A}(\mathbf{B i})\end{array}$ & Level \\
\hline S1 & S1, S3 & S1 & S1 & II \\
\hline S3 & S3 & S1, S3 & S3 & \\
\hline
\end{tabular}

Table 6. Iteration III

\begin{tabular}{|c|c|c|c|c|}
\hline $\begin{array}{l}\text { Factors } \\
(\mathrm{Si})\end{array}$ & $\begin{array}{l}\text { Reachability set } \\
\text { R (Si) }\end{array}$ & $\begin{array}{l}\text { Antecedent set } \\
\text { A (Si) }\end{array}$ & $\begin{array}{l}\text { Intersection set } \\
\mathbf{R}(\mathbf{S i}) \cap \mathbf{A}(\mathbf{S i})\end{array}$ & Level \\
\hline S1 & S1 & S1 & S1 & III \\
\hline
\end{tabular}

The conical matrix is built from the final RM, the factors are grouped in the same level across the rows and the columns, as presented in the Table 8 . The driver power of the factor is derived by summing up the number of ones (1) in the rows and its dependence power by summing up the number of ones (1) in the columns. Then, in order to have a ranking for the factors, the highest rank are the identified factors with the maximum number of ones (1) in the rows and columns of drive power and dependence power respectively [33,34]. The driving power of a factor equals to the sum of all values in each row of the final RM matrix and describes the number of factors that can be influenced by the factor being analyzed. To the other hand, the dependence power of the factor is the addition of all the values in each column of the final RM matrix, thus presenting the number of factors that can influence that factor [36] as shown in the table 8. From the conical matrix, the initial digraph including transitive links is built. The digraph is used to represent the identified factors in terms of nodes and edges also; is the visual representation of the identified factors and their interdependences [33, 34]. In this development, the top level factor is located at the top of the digraph and the second level factor is positioned at second position and so on, until the bottom level is placed at the lowest position in the digraph as describe in the Fig. 2. [34].

Step4: constructing the conical matrix and digraph 
Table 7. Conical matrix

\begin{tabular}{|c|c|c|c|c|c|c|c|c|}
\hline \multicolumn{2}{|l|}{ Factors (Bi) } & S2 & S4 & S6 & S5 & S3 & S1 & $\begin{array}{l}\text { Driving } \\
\text { power }\end{array}$ \\
\hline Product & $\mathrm{S} 2$ & 1 & 1 & 1 & 1 & 0 & 0 & 4 \\
\hline Working practices & S4 & 1 & 1 & 1 & 1 & 0 & 0 & 4 \\
\hline Regulations & S5 & 1 & 1 & 1 & 1 & 0 & $\mathrm{O}$ & 4 \\
\hline Installation & S6 & 1 & 1 & 1 & 1 & 1 & 0 & 5 \\
\hline Nature of the task & S3 & 1 & 1 & 1 & 1 & 1 & 0 & 5 \\
\hline $\begin{array}{l}\text { meteorology } \\
\text { conditions }\end{array}$ & $\mathrm{S} 1$ & 1 & 1 & 1 & 1 & 1 & 1 & 6 \\
\hline Dependence power & & 6 & 6 & 6 & 6 & 3 & 1 & $28 / 28$ \\
\hline
\end{tabular}

Step5: developing an ISM model and MICMAC analysis In order to obtain an ISM model, the nodes and edges are replaced by the identified factors statements [33, 34]. Moreover, from its French definition, matrice d'impact croises-multiplication applique au classement (cross-impact matrix multiplication applied to classification), MICMAC analysis was first developed by Duperrin and Godet in 1973 to analyze the drive power and dependence power of factors. MICMAC analysis is done to identify the key factors that drive the system in various categories. In relation to their drive power and dependence power, factors are classified into four categories such as autonomous factors, linkage factors, dependent factors, independent factors $[33,34,35,36]$. The first category autonomous factors; these factors have weak drive power and weak dependence power. There are relatively disconnected from the system, with which they have few links, which may be very strong. The second category linkage factors; these factors have strong drive power as well as strong dependence power. These factors are unstable in the way that any action on these factors will have an effect on others and also a feedback effect on themselves. The third category dependent factors; these factors have weak drive power but strong dependence power. And finally the fourth category independent factors; these factors have a strong drive power but weak dependence power. A factor with a very strong drive power, called 'key factor' falls onto the category of independent or linkage factors as presented in Fig. 2 [33,34]. The results of our study cover the ISM digraph analysis and the MICMAC analysis presented in the Fig. 2 and Fig. 3 respectively.

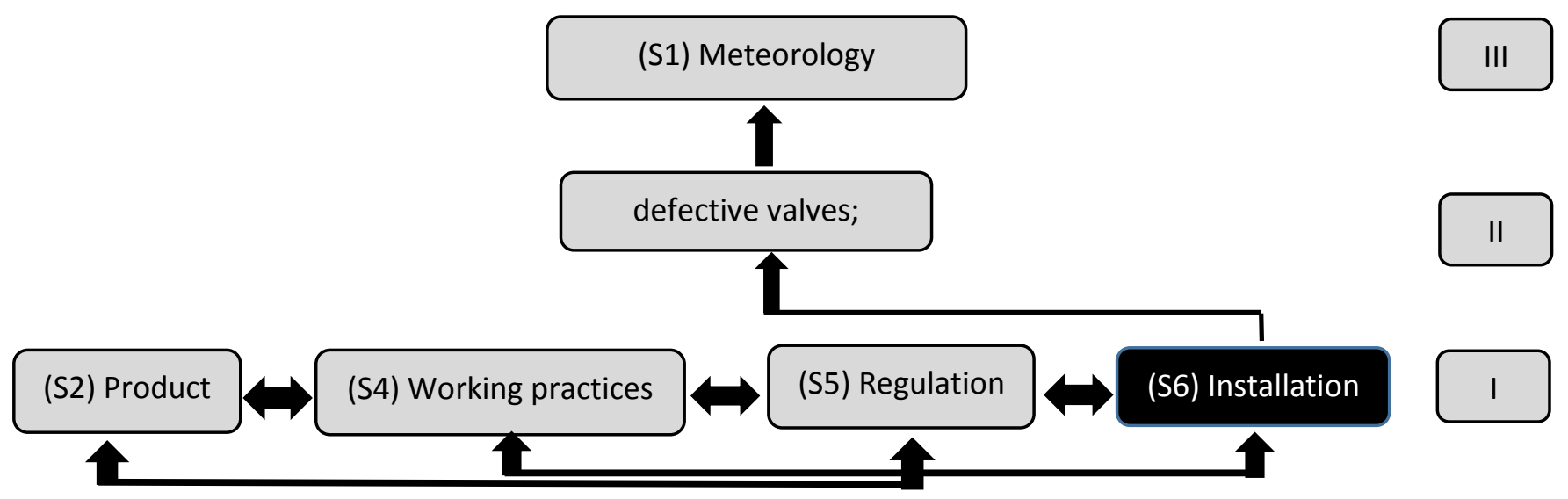

Fig. 2. Digraph showing levels of benzene exposure identified factors 
From the ISM digraph, the 6 identified factors were partitioning in 3 levels. In the level I, four identified factors were found such as (S2) 'product', (S4) ''working practices", (S5) 'regulation', (S6) 'installation'. The four identified factors occupy the lowest position in the digraph. These identified factors are not impacted by any other identified factor; hence they appear at the bottom of the ISM hierarchy. These identified factors have the most priority to be look at in gasoline storage and distribution facility in developing countries. Then, identified factor (S3) "Nature of the task" is the next priority as a result of being positioning in the level II of the ISM hierarchy. This is middle-level identified factor being impacted by lower-level and affecting the upper-level ones. Finally, the identified factor (S1) "meteorology conditions", is the less important identified factor to be looking at gasoline storage and distribution facility in developing country. This is the identified factor being affected by the lower-level identified factor. For the MICMAC analysis, the driver-dependence matrix figure shows that in the cluster I, autonomous factor there is no identified factor located in that area. Autonomous factor is the area in the figure with the weak driving power and dependence power and, it does not impact on the system. The lack of autonomous factor implies that all the identified factors play a significant role in influencing benzene exposure concentration at the GSDF in developing country. Although, priorities are set among the identified factors, management should pay attention to consider all the identified factors to be tackled one after the other. At the cluster II, there are no identified factors into that area of the drive-dependence matrix figure. The dependence factor is the zone in the figure which has weak drive power and strong dependence power. The absence of dependence factor indicates that most of the identified factors are roots cause of benzene exposure concentration at the GSDF. And then, quasi no identified factors depend to other identified factor to influence the benzene exposure concentration. Therefore, management has no need to focus on the understanding of the relationship between other levels of identified factor in the ISM model, because the priority identified factors are already known and need to be tackled to make inexistent the other dependence factors.

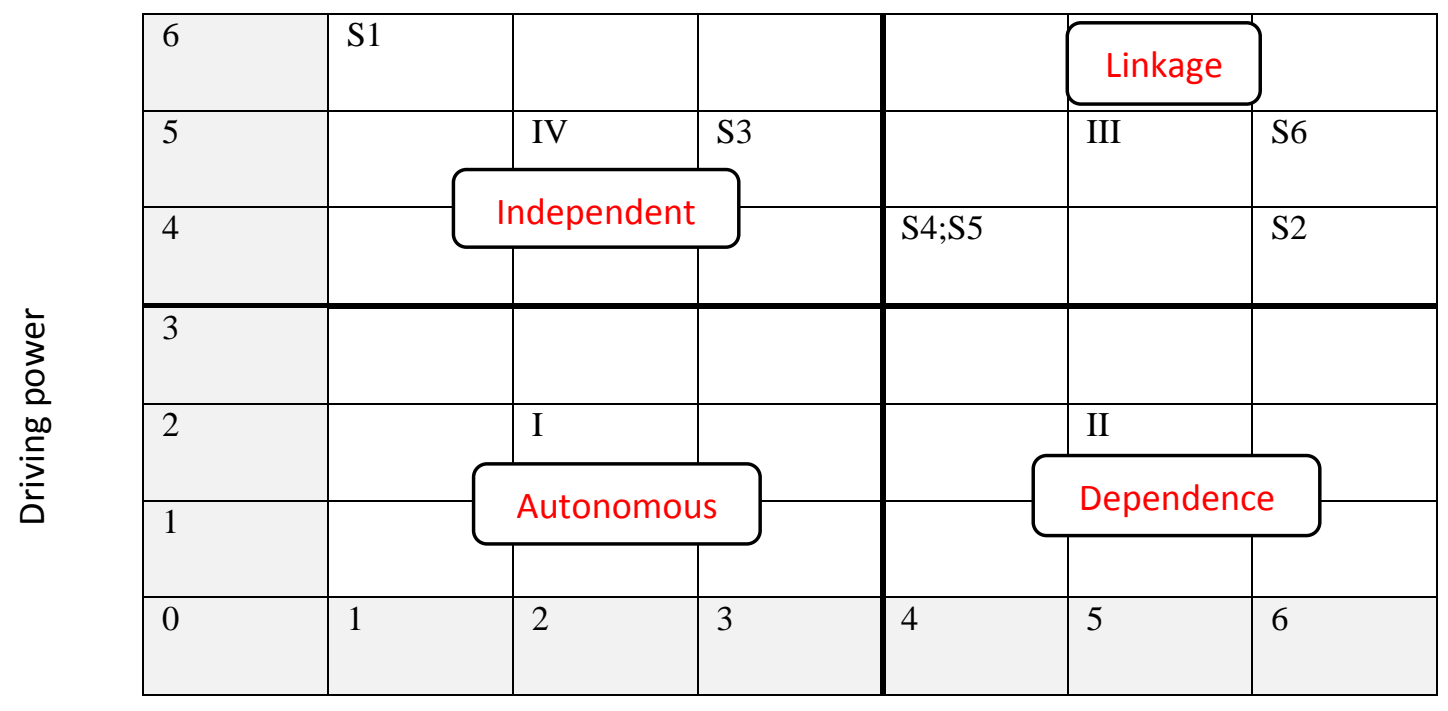

Dependence power

Fig.3 Driver-Dependence matrix of the benzene identified factors

In the cluster III, four identified factors are located in the figure 3, such as '"product', ''regulation", ',working practices', and 'installation'. The linkage factor is the area in the figure with a high driving power and strong dependence power. This implies that these identified factors to influence benzene exposure concentration, are all impacted at the same time. And then, from a change only one identified factor all the other identified factors are impacted to influence the benzene exposure concentration. In other to tackle these identified factors, management should conduct training and monitoring an in-house procedure for a task implementation. Finally, in the cluster IV two identified factors were located such as "nature of the task" (S3) and "meteorology condition" (S1). The independent factor is the zone in the figure which has a strong drive power and weak dependence power. This indicates that the two identified factors located in independent area are independent regardless to the impact they have respectively to that benzene concentration in loading operation for storage and distribution facility in developing countries. Each of these two identified factors influence benzene exposure concentration at their respective level independently. This study, revealed a total of 23 specific sub- 
factors that influence benzene exposure concentration during loading operations. The 23 sub-factors were identified in the literature review from studies focusing on benzene exposure during loading operations. These 23 sub-factors were then, grouped into 6 identified factors. The identified factors were selected through more generic factors that can impact a risk exposure assessment during a loading operation and with the experts' opinions on those factors. The 6 identified factors covered the overall exposure scenario for loading operation and are common to developing countries facilities. The rank of the identified factors was observed at 2 levels, through the experts' opinions and ISM hierarchy. From the experts' opinions, the scores assigned to each identified factor was influenced by the number of questionnaire survey obtained. At the ISM hierarchy, the Fig. 2. Shows the priority in terms of which identified factor (s) should be tackle first.

From the ISM model, several interactions between the 6 identified factors which influence benzene exposure concentration during loading operations were disclosed. This is well illustrated from the SSIM matrix to the digraph. In the digraph, from the level I, only the identified factor " (S5) Installation" and " (S2) Product" are interacting in other to influence benzene exposure concentration. Then, to be connected to the next level, only the identified factor " (S5) Installation" in the level I is connected to the identified factor " (S3) Nature of the task" of the level II. Finally, the identified factor " (S3) Nature of the task" is connected to the identified factor " (S1) Meteorology conditions" of the level III. The results of this study, for loading operations of gasoline in developing countries have identified 6 factors that must be assessed; and among them 4 factors should be tackled first. This implies for the hierarchy level I in the ISM model, to reduce the benzene contain in the gasoline product from the refinery. A continuous training and educating workers on working procedures. Developing a watch regulations and laws that could impact negatively the loading operations and finally an updating of the facility with the implementation of engineering control measures, such as vapor recovery system. At the level II hierarchy, resulting of the combination of providing the appropriate personal protective equipment and continuous training on working procedure. Finally, for the level III hierarchy, a collective protective equipment and upgrade of the operation mode, such as automation are necessary to prevent and protect workers' health.

\subsection{Limitations and scope of the future research work}

In this study, the ISM model and MICMAC analysis were applied for 6 identified factors as a result of analyzing the factors that influence occupational benzene exposure concentration in loading operations at gasoline storage and distribution facility for developing countries. However, the limitation on relevant articles from the literature survey, and from which the quality of the study rely on, might affected the results with some element of bias. Having analyze the factors influencing occupational benzene exposure concentration during loading operation at storage and distribution facility in developing countries, assessment of suitable factors from benzene exposure at storage and distribution facility would be crucial for the workers' health protection. Although, the study has some limitations the results were worthwhile to help describing the current challenges that gasoline storage and distribution facilities in developing countries experience.

\section{CONCLUSION}

The analyzing of factors influencing occupational benzene exposure concentration in loading operations at GSDF in developing countries, has enabled to identify 23 sub-factors influencing benzene exposure concentration from the literature review, and grouped into 6 main factors. Then, the degree of importance of these factors was assessed through their respective ranking. Moreover, the interaction and relationship among the factors was elucidate, which contributed to first identified the most important factors to tackle when conducting an exposure assessment in gasoline storage and distribution facility in developing country and the behavior of the factors. The above information is crucial to strategize, in other assess benzene exposure in at GSDF country. From the questionnaire-based survey, factors influencing benzene concentration during loading operation were identified and ranked based on respondents' results, with the factor product (S2) being the $1^{\text {st }}$ rank and regulations (S5) last influential factor as shown in the table 3. The ISM model discloses the three levels of hierarchy that exist in this study and the interactions between the factors working practices (S4); installation (S6); regulations (S5) and product (S2) at the level 1. The results of this study has pointed out four identified factors such as product (S2); working practices (S4); regulations (S4) and installation (S6) which are the influential factors to benzene exposure concentration at the gasoline storage and distribution facility in developing countries. The management should take into consideration the priority disclosed in terms of factors to be tackled and the behavior pattern of these factors when conducting an exposure assessment.

\section{ACKNOWLEDGMENTS}

This research would have not been possible without the support of several people. The author would like to thanks to all those who cooperated and participated in this research, including members of Tokai Laboratory in Environmental Management of Osaka University. This research was completed with support from the Ministry of Education, Culture, Sports, Science, and Technology of Japan (MEXT), (Grant No. 150768) through its postgraduate scholarship program for foreign students. 


\section{REFERENCES}

[1] Carolyn F. Phillips CF, Robert K. JONES RK. Gasoline vapor exposure during bulk handling operations. American Industrial Hygiene Association Journal. 1978; Volume 39: 1978 - Issue 2/ Pages 118-128.; 04 Jun 2010.

[2] J. Paul Guyer 2014. An Introduction to Petroleum Fuel Facilities: Bulk Fuel Storage. Continuing Education and Development, Inc. 9 Greyridge Farm Court Stony Point, NY 10980 P: (877) 322-5800 F: (877) 322-4774 info@cedengineering.com.

[3] G.H. Pandya, A.G. Gavane and V.K. Kondawar. Assessment of Occupational Exposure to VOCs at the Gantry Gasoline Terminal. JOURNAL OF ENVIRON. SCIENCE \& ENGG. VOL. 48, No. 3, P. 175 -182, July 2006.Development, Inc. 9 Grey ridge Farm Court. Stony Point, NY 10980. 6.

[4] Igor Burstyn, Xiaoqing (Isabelle) Nicola Cherry Ambikaipakan, Senthilselvan. Determinants of airborne benzene concentrations in rural areas of western Canada. https://doi.org/10.1016/j.atmosenv.2007.06.011 Atmospheric Environment. Volume 41, Issue 36, November 2007, Pages 7778-7787

[5] Parkinson GS (1971) Benzene in motor gasoline _ an investigation into possible health hazards in and around filling stations and in normal transport operations. Ann Occup Hyg 14, 145-153

[6] Sherwood, RJ (1972) Evaluation of exposure to benzene vapor during loading of petrol. Br J Ind Med 29:65-69 Received Match 5, 1990; accepted June 4, 1990.

[7] GjOrloff K, Skardin B, Svedung I (1982): Cited from Holmberg B, Lundberg P (1985). Berlin M (1988) Biological monitoring of populations exposed to volatile petroleum products. Ann NY Acad Sci 534:472-480. GjOrloff K, Skardin B, Svedung I (1982): Cited from Holmberg B, Lundberg P (1985).

[8] Runion, H.E. and Scott, L.M. (1985) Benzene exposure in the United States 1978-1983: an overview. Am. J. Ind. Med. 7,385-393.

[9] Halder CA, Van Gorp GS, Hatoum NS, Warne TM (1986). Gasoline vapor exposures. Part I. Characterization of workplace exposures. Am. Ind. Hyg. Ass. J 47:164-172.

[10] Berlin M (1988) Biological monitoring of populations exposed to volatile petroleum products. Ann NY Acad Sci 534:472-480.

[11] Verma DK, Jim A. Julian JA, Gail Bebee G, Wai K. Cheng WK, Holborn K, Shaw L. Hydrocarbon exposures at petroleum bulk terminals and agencies. American Industrial Hygiene Association Journal 1992; 53(10): Pages 645-656, (1992). http://dx.doi.org/10.1080/15298669291360292.

[12] Behzad Heibatia, Krystal J. Godri Pollitt, Jamshid Yazdani Charati, Alan Ducatmand. Ali Karimi, f Mahmoud Mohammad yang. Biomonitoring-based exposure assessment of benzene, toluene, ethylbenzene and xylene among workers at petroleum distribution facilities. Ecotoxicology and Environmental Safety Volume 149, March 2018, Pages 19-25 https://doi.org/10.1016/j.ecoenv.2017.10.070.

[13] Verma DK, Diane M. Johnson DM, M. Lorraine Shaw ML, Karen Des Tombe K. Benzene and Total hydrocarbons exposures in downstream petroleum industries. American Industrial Hygiene Association Journal, 2001;62:176-194 (2001) Pages 176-194. http://dx.doi.org/10.1080/15298660108984621

[14] IARC (1987). Overall evaluations of carcinogenicity: an updating of IARC Monographs volumes 1 to 42 . IARC Monogr Eval Carcinogens Risks Hum Suppl, 7: 1-440. PMID:3482203

[15] Navasumrit P, Chanvaivit S, Intarasunanont P, Arayasiri M, Lauhareungpanya N, Parnlob V, Settachan D, Ruchirawat M. Environmental and occupational exposure to benzene in Thailand Chem Biol Interact. 2005 May 30;153-154:75-83. Epub 2005 Apr 1.

[16] Keretetse G.S., Laubscher P.J., du Plessis J.L., Pretorius P.J., van der Weshuizen F.H., van Dyk E., Eloff F.C., Arde M.N., du Plessis L.H. DNA damage and repair detected by the comet assay in lymphocytes of African petrol attendants: A pilot study. Ann. Occup. Hyg. 2008 ; 52:653-662. http://dx.doi:10.1093/annhyg/men047. [PubMed] [CrossRef]

[17] Cheremisinoff and Morresi, 1979; P.N. Cheremisinoff, A.C. Morresi. Benzene, Basic and Hazardous Properties. Marcel Dekker, New York (1979), p. 250. Google Scholar.

[18] Tunsaringkarn T, Siriwong W, Rungsiyothin A, Nopparatbundit S. Occupational Exposure of Gasoline Station Workers to BTEX Compounds in Bangkok, Thailand. The International Journal of Occupational and Environmental Medicine 2012;3:117-25. 
[19] TIN Ezejiofor, HC Nwigwe, FOU Osuala, MOE Iwuala Appraisals for potential hazards in the operational environment and facilities of petroleum refining and distribution industry in Nigeria. Journal of Medical Investigation and Practice, Year: 2014 | Volume: 9 | Issue: 1 | Page: 39-42. http://www.jomip.org/text.asp?2014/9/1/39/132558.

[20] Monney, John Bosco Dramani, Abigail Aruna, Asantewa Gyamfi Tenkorang, Fred Osei-Poku Health and safety in high-risk work environments: A study of fuel service stations in Ghana. Isaac Journal of Environmental and Occupational Science.

[21] T. Kawai, K. Yamaoka, Y. Uchida, and M. Ikeda. Exposure to Vapors of Benzene and Other Aromatic Solvents in Tank Truck Loading and Delivery. Osaka Occupational Health Service Center, Osaka 550, Japan and Department of Public Health, Kyoto University Faculty of Medicine, Kyoto 606, Japan.

[22] W.S. Irving WS, Thomas G. Grumbles TG. Benzene exposures during gasoline loading at bulk marketing terminals. American Industrial Hygiene Association, J 1979;40:468-736. http://dx.doi.org/10.1080/15298667991429840. Toxicology Letters, 52 (1900) 135-139, 1990.

[23] Nordlinder R, Ramnas O. EXPOSURE TO BENZENE AT DIFFERENT WORK PLACES IN SWEDEN. The Annals of Occupational Hygiene, Volume 31, Issue 3, 1 January 1987, Pages 345-355, https://doi.org/10.1093/annhyg/31.3.345

\section{[24] U.S.EPA-450. CONTROL OF HYDROCARBONS FROM TANK TRUCK GASOLINE LOADING TERMINALS. EPA-450/2-77-026 (OAQPS NO. 1.2-082).}

[25] Julie Yu and Harris Cooper. A Quantitative Review of Research Design Effects on Response Rates to Questionnaires. Journal of Marketing Research. Vol. 20, No. 1 (Feb., 1983), pp. 36-44 Published by: Sage Publications, Inc. https://DOI:10.2307/3151410

[26] MSAFIRI M. JACKSON. ORGANIC LIQUIDS STORAGE TANKS VOLATILE ORGANIC COMPOUNDS (VOCS) EMISSIONS, DISPERSION AND RISK ASSESSMENT IN DEVELOPING COUNTRIES: THE CASE OF DAR-ES-SALAAM CITY, TANZANIA. Environmental Monitoring and Assessment (2006) 116: 363-382 https://DOI:10.1007/s10661-006-7573.

[27] S. Raghavan \& K. Basavaiah. Biological monitoring among benzene-exposed workers in Bangalore city, India Pages 336-341 | Received 10 May 2005, Published online: 08 Oct 2008. https://doi.org/10.1080/13547500500274206.

[28] Cruz-Núñez, X., Hernández-Solís, J.M., Ruiz-Suárez, Evaluation of vapor recovery systems efficiency and personal exposure in service stations in Mexico City. Science of the Total Environment Volume 309, Issue 1-3, 20 June 2003, Pages 59-68.

[29] Dimosthenis A. Sarigiannis, Spyros P. Karakitsios, Alberto Gotti, Costas L. Papaloukas, Pavlos A. Kassomenos and Georgios A. Pilidis. Bayesian Algorithm Implementation in a Real Time Exposure Assessment Model on Benzene with Calculation of Associated Cancer Risks. Sensors 2009, 9, 731-755; https://doi:10.3390/s90200731 Sensors. ISSN 14248220 .

[30] Eun Kyo Chung Jae Kil Jang Dong Hee KohA comparison of benzene exposures in maintenance and regular works at Korean petrochemical plants Journal of Chemical Health and Safety Volume 24, Issue 3, May-June 2017, Pages 21-26 https://doi.org/10.1016/j.jchas.2016.09.006

[31] Tuomi T, Veijalainen H, Santonen. Managing Exposure to Benzene and Total Petroleum Hydrocarbons at Two Oil Refineries 1977-2014. Int J Environ Res Public Health. 2018 Jan 24;15(2). pii: E197. http://dx.doi:10.3390/ijerph15020197

[32] Tran Thi Ngoc Lana Ngo Quang Liema Nguyen Thi Thanh Binh b. Personal exposure to benzene of selected population groups and impact of commuting modes in Ho Chi Minh, Vietnam. Volume 175, April 2013, Pages 56-63 Environmental Pollution https://doi.org/10.1016/j.envpol.2012.12.017

[33] Rajesh Attri, Nikhil Dev, and Vivek Sharma. Interpretive Structural Modelling (ISM) approach: An Overview. Research Journal of Management Sciences. Vol. 2(2), 3-8, February (2013) Res. J. Management Sci. International Science Congress Association.

[34] Rajesh Attri - Sandeep Grover • Nikhil Dev • Deepak Kumar. Analysis of barriers of total productive maintenance (TPM) . Int J Syst Assur Eng Manag (Oct-Dec 2013) 4(4):365-377 https://DOI10.1007/s13198-012-0122-9

[35] Leticia Sarmentodos Muchangos, AkihiroTokai, Atsuko Hanashima. Analyzing the structure of barriers to municipal solid waste management policy planning in Maputo city, Mozambique. Volume 16, December 2015, Pages 7689Environmental Development. https://doi.org/10.1016/j.envdev.2015.07.002 
Asian Journal of Applied Sciences (ISSN: 2321 - 0893)

Volume 07 - Issue 01, February 2019

[36] Shankar Chandramowli, Morghan Transue Frank A.Felder. Analysis of barriers to development in landfill communities using interpretive structural modeling. Volume 35, Issue 2, April 2011, Pages 246-253 Habitat International. https://doi.org/10.1016/j.habitatint.2010.09.005 